Pamiętnik Literacki 2018, 3, s. 165-188

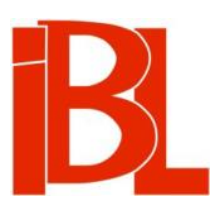

\title{
Wojenne wspomnienia Władysława Reymonta - nieznany rękopis
}

\author{
Oprac. Dariusz Pachocki
}


Pamiętnik Literacki CIX, 2018, z. 3, PL ISSN 0031-0514

DOI: $10.18318 / \mathrm{pl} .2018 .3 .11$

\title{
WOJENNE WSPOMNIENIA WŁADYSŁAWA REYMONTA - NIEZNANY REKOPIS
}

\author{
Opracował \\ DARIUSZ PACHOCKI Katolicki Uniwersytet Lubelski Jana Pawła II
}

Władysław Reymont marzył o wyprawie za ocean ${ }^{1}$. Ze swych pragnień zwierzył się m.in. dziennikarzowi polonijnemu Wojciechowi Morawskiemu w liście z 1907 roku. Artysta dopytywał się o koszty utrzymania, ale pisał też wprost, co go do transoceanicznej podróży determinuje:

Nie pociaga mnie ani Wasz ustrój polityczny, bo jest dla mnie równie zły jak i nasze, ni Wasze demokracje, również miłe jak u nas, ale pociaga mnie wprost potęga indywidualna Amerykanów. I dlatego prędzej czy później muszę tam być i własnymi oczami zobaczyć².

Amerykańska wyprawa była dla Reymonta istotna także z powodów zawodowych. Planował zbieranie materiałów do powieści. Wspominał o tym współuczestnik jednej $z$ jego podróży - Zdzisław Dębicki:

O powieści takiej marzył od dawna, jako o koniecznym dopełnieniu Chłopów, uważając, iż nie ma pełnego obrazu życia ludu bez wychodźstwa, iż to wychodźstwo odgrywa rolę tak dużą, że pomijanie go przez literaturę jest rzeczą karygodną ${ }^{3}$.

W przekonaniu Reymonta nikt ze środowiska, które miał zamiar opisać, nie mógł wykreować tego typu utworu, gdyż w większości byli to analfabeci.

Zamysł artysty pokrzyżowała wojna, ale tuż po jej zakończeniu pojawiła się szansa na wyjazd. Wiązała się ona ściśle z sytuacją wewnętrzną w kraju po odzyskaniu niepodległości. Pośród głównych problemów młodej państwowości znajdowała się kwestia granic. Reymont jako jeden z 23 twórców - sygnował Odezwę Zwiazku Pisarzów Orła Białego w sprawie obrony kresów. Jego zaangażowanie w politykę miało wkrótce pomóc mu w spełnieniu marzenia o wyprawie za ocean. 23 I 1919 artystę zaprosił do Belwederu Józef Piłsudski. Spotkanie to zostało przypieczętowane skierowaniem Reymonta do Stanów Zjednoczonych (via Paryż) z misją dyplomatyczną. Na zlecenie rządu miał objechać polonijne ośrodki, by promować ideę nowo powstałego państwa polskiego. Jerzy Ryszard Krzyżanowski, starający się zrekonstruować amerykańską podróż artysty, stwierdził:

Spodziewano się, że pisarz znajdzie wspólny język z emigrantami i ukazać im potrafi problemy, w których rozwiązaniu Polonia mogłaby pomóc i że obiektywnie potrafi naświetlić sytuację w Polsce ${ }^{4}$.

1 Więcej na ten temat zob. S. S o bi e r aj, Ameryka Reymonta. Między Polonia a Nowym Światem. „Acta Universitatis Lodziensis” 2008, nr 11.

2 Reymont $w$ Ameryce. Listy do Wojciecha Morawskiego. Oprac., wstęp L. Orłowski. Warszawa 1970, s. 80, list z 23 III 1907.

3 Z. Dę bi cki, Reymont w Ameryce. „Tygodnik Ilustrowany” 1926, nr 2, s. 34.

4 J. R. Krzyża now s ki, Reymont w Stanach Zjednoczonych. „Ruch Literacki” 1970, nr 3, s. 206. 
Niestety, nie zachowało się zbyt wiele dokumentów dotyczących wizyty Reymonta za oceanem, jednak wiemy, iż przebywał tam od 2 VI do 17 IX 19195. Natomiast pierwsze publiczne wystapienie miało zapewne miejsce 20 VI $1919 \mathrm{w}$ Chicago ${ }^{6}$. Prezentowany tu tekst wspomnień najprawdopodobniej wtedy właśnie został wygłoszony. Zestawiając go $z$ fragmentami innych mów, które drukowano w prasie ${ }^{7}$, można zauważyć, iż były one podobne w duchu, choć nietożsame w treści. Indywidualne przygotowywanie i wygłaszanie kolejnych wystąpień musiało pisarza wiele kosztować. Tym bardziej że klimat zupełnie mu nie służył. Reymont bardzo źle znosił upały. Skarżył się na to w liście do Morawskiego: „Klimat tutejszy nie dla mnie jednak, moje nerwy reagują do tego stopnia, że często muszę leżeć całymi godzinami w samotności, żeby zebrać nieco sił"8. Ponadto artysta cierpiał duchowo. Pisał o tym do różnych osób, wśród których był Morawski, wspierający wyprawę Reymonta od strony organizacyjnej:

Ameryka dotychczas zdumiewa mnie, ale właśnie i dlatego może czuję się tutaj coraz bardziej obcym. To nie mój rytm życia, a przy tym czuję się nazbyt samotnym duchowo. Na szczęście te nasze masy ludowe pociagają mnie bardzo i serdecznie wzruszają swoją siłą, ofiarnością i patriotyzmem. To jedynie powstrzymuje mnie od dezercji. Bo już nieraz chciało mi się uciekać9 .

Reymont pisał takie słowa po 3 tygodniach pobytu. Przed sobą miał jeszcze gorace lato i wiele spotkań z amerykańską Polonią. Wśród odwiedzonych w tym czasie miast były m.in. Nowy Jork, Chicago, Detroit, Ann Arbor, Buffalo, Pittsburgh. Autor Ziemi obiecanej wygłosił ponad 30 odczytów $^{10}$. Trudy pobytu rekompensowały mu wzruszające reakcje ludzi. Zwracał na to uwagę później Dębicki, który wchodził w skład delegacji rządowej:

Pamiętam jedną niezapomnianą scenę. Byliśmy na wiecu ludowym w Filadelfii. Na jakimś pustym placu, gdzie wzniesiono improwizowaną estradę z goły ch, nieheblowanych desek, zebrał się tłum liczący do 2000 osób. Nas usadowiono na estradzie w towarzystwie mera miasta i innych dygnitarzy. Przemawiałem z tej estrady do zgromadzonych. Efekt był nadspodziewany. Po skończeniu przemówienia zaczęła się subskrypcja pożyczki. Podchodzili jednak ludzie, którzy nie umieli pisać. Po prostu kładli na stół pieniądze „dla Polski”"

Ponadto - jak podkreślał Dębicki - Reymont wolał gawędzić, niż przemawiać. Wystąpienia publiczne wiele go kosztowały i niejednokrotnie prosił o zastępstwo. Natomiast poza sceną dość sprawnie potrafił zaskarbić sobie przychylność rozmówców. W sytuacjach nieformalnych czuł się dużo swobodniej ${ }^{12}$.

Pod koniec sierpnia 1919 w jednym z listów do siostry, Katarzyny Jakimowiczowej, Reymont pisał o swej tęsknocie i lękach:

Ministerstwo Spraw Wewnętrznych 21 I 1919 skierowało Reymonta z misją dyplomatyczną do Berna, Paryża (od 18 I 1919 odbywała się tam Konferencja Pokojowa) i do Stanów Zjednoczonych Ameryki Północnej. Wyprawa do Ameryki rozpoczęła się 15 IV 1919 statkiem „Canada” z Marsylii do Nowego Jorku. Relację ze swej podróży pisarz opublikował w „Kurierze Warszawskim” (1935, nr 353).

6 Zob. W. S. Rey mo nt, Dziennik nieciagty 1887-1924. Oprac. B. Utkow ska. Kraków 2009, s. 219.

7 Zob. Reymont analizuje wojnę. „Sokół Polski” 1919, nr z 25 IX, s. 3. Cyt. za: Krzyża now s ki, op. cit., s. 207.

8 Reymont $w$ Ameryce, s. 82, list z 27 VI 1919.

9 Ibidem, s. 82-83.

10 Zob. Sobieraj, op. cit., s. 89-90. - Rey mo nt, op. cit., s. 218-219.

11 Dębicki, op. cit., s. 35-36.

12 Ibidem. 
nie za cały miesiąc wsiadam na okręt i powracam. Do Warszawy chcę zdążyć na 10 października. Już liczę dnie dzielące mnie od powrotu. Może nigdy tak nie tęskniłem.

Muszę jeszcze objechać parę miast najbliższych Nowego Jorku, co mi zajmie ze trzy tygodnie, no i koniec będzie mojej włóczędze. Trzymam się jako tako, boję się chorować, a zwłaszcza umierać pomiędzy obcymi. $Z$ kraju mam niezmiernie rzadkie wiadomości ${ }^{13}$.

Autor Ziemi obiecanej szczęśliwie dotarł do domu i zaraz po przyjeździe rzucił się w wir pracy. W rozmowach z dziennikarzami Reymont zwracał uwagę na zaangażowanie Polonii amerykańskiej w sprawy ojczyzny:

Przede wszystkim należałoby uczcić dobrowolną ofiarę krwi poniesioną przez amerykańskich Polaków podczas wojny [...]. Sam „Sokół” amerykański wystawił 12000 świetnego żołnierza. Rozmach, animusz, zapał polski zaimponował jankesom. Dziś liczą się z Polakami nie tylko jako państwem, ale jako z czynnikiem dzielnym, energicznym i męskim [...].

Ani nam się nie śniło, jakie pieniądze zebrała ta szara chłopska i robotnicza brać nasza w Ameryce. Oto okragły miliard dolarów, czyli przeszło 30 miliardów marek! Łatwo sobie wyobrazić, co znaczy dla naszego zbiedzonego kraju ten ogromny kapitał, zwłaszcza w tęgich i obrotnych dłoniach [...]. Tymczasem tam, w Ameryce, rodacy nasi w niecierpliwych swych marzeniach dźwigają nasz kraj, odbudowują miasta i wsie, puszczają w ruch warsztaty i fabryki, kłada podwaliny pod nowy twórczy okres „pracy organicznej”"14.

Zapominając o minionych, trudnych przecież, doświadczeniach, artysta niemal natychmiast podjął starania o kolejny wyjazd do Ameryki. Działania te zostały uwieńczone sukcesem. W Archiwum Państwowym w Poznaniu zachował się Dekret Ministerstwa Skarbu mianujący Reymonta członkiem Delegacji Rządu Polskiego (z 24 IV 1920), udającej się do Stanów Zjednoczonych w celu uzyskania pożyczki dla Polski, podpisany przez Władysława Grabskiego $^{15}$. Tym razem podróż trwała od maja do połowy lipca $1920^{16}$.

Autor Ziemi obiecanej dość mocno odchorował amerykańskie wojaże. Kłopoty z sercem i upały nie wpływały pozytywnie na jego samopoczucie i zniechęcały do intensywnego zaangażowania się w sprawy, do których został powołany. Odczyty i wystąpienia publiczne bardzo go zmęczyły. $Z$ drugiej strony, bardzo chciał do Ameryki wrócić. Przede wszystkim, by promować tam swą twórczość ${ }^{17}$. Dlatego też myślał o wykładach nie dla Polonii, lecz dla amerykańskiej inteligencji. Chciał im opowiedzieć o polskiej historii, teraźniejszości oraz

W. S. Rey mon t, Listy do rodziny. Oprac. T. J odełka-Burze cki, B. Ko cówna. Warszawa 1975, s. 246, list z 24 VIII 1919.

Polacy w Ameryce. „Nowiny Raciborskie” 1919, nr 178, z 24 X, s. 1.

15 Dekret Ministerstwa Skarbu. W: B. K o c ów na, Cz. H r u s z k a, Reymont w Kołaczkowie. „Przegląd Humanistyczny" 1973, nr 1, s. 128.

16 Zob. B. Ko c, Reymont. Opowieść biograficzna. Wyd. uzup i popr. Warszawa 2000, s. 167-168: „Po kilku miesiącach pobytu w kraju, przerywanym nota bene wyjazdem do Paryża w charakterze członka delegacji polskiej, która brała udział w pracach przygotowawczych do Kongresu Pokoju (w grudniu 1919), Reymont znalazł się na parowcu "New York", wyruszając z Cherbourga znowu do Ameryki. Wyjeżdżał w końcu kwietnia 1920 roku jako jeden z uczestników delegacji Ministerstwa Skarbu, z Franciszkiem Stefczykiem na czele. Towarzyszył mu również Zdzisław Dębicki. Tym razem chodziło o propagowanie pożyczki dolarowej, emitowanej przez rząd polski w Stanach Zjednoczonych Ameryki Północnej za pośrednictwem The People’s Industrial Trading Corporation of The United States. Szlak wyprawy obejmował New York, Washington, Filadelfię, Baltimore, Chicago itp."

17 Na temat tłumaczeń utworów Reymonta na język angielski zob. H. D zi i n dziel, O Reymoncie. Wspomnienia. Warszawa 1972, s. 91. - K o c, op. cit., s. 163-171. - F. Zi ej ka, „Chtopi” Wtadysława S. Reymonta $w$ drodze do światowej sławy. „Niepodległość i Pamięć” 2015, nr 1. 
literaturze. W liście do Morawskiego zaproponował rozwiązanie, które oszczędziłoby mu sił i stresu:

Kiedyś przed wojna, kiedy Przybyszewski był u zenitu sławy i powodzenia, zaproponowano mu szereg odczytów po wielkich miastach rosyjskich. Jużci po rosyjsku. Miały to być odczyty dla Rosjan. P. po rosyjsku nie umiał. Jakież znaleźli wyjście? Przetłumaczono te odczyty na rosyjski język i na trybunę wchodził Przybyszewski, zagajał parę słów po rosyjsku, siadał i odczyt ów czytał tłumacz! Bardzo się ta impreza podobała i zyskała wielkie powodzenie ${ }^{18}$.

Tłumaczem miałby zostać adresat, który jednak nie zapałał entuzjazmem do owego pomysłu. W kolejnych listach Reymont nie wracał do tej idei. Sam fakt, że zrodziła się ona w wyobraźni pisarza, ilustruje, jak bardzo był zdeterminowany, by do Stanów Zjednoczonych wrócić. Zamysłów takich już nigdy nie udało mu się zrealizować. Publikowany tu dokument stanowi jedno ze świadectw $z$ jego zaangażowania w sprawy Polski za oceanem. Dość istotna w tym kontekście jest także próba zmierzenia się ze wspomnieniami, które przesycone były wojennymi okropnościami. Obrazy przywoływane przez pisarza podczas wystapień publicznych zapewne robiły na słuchaczach duże wrażenie. Nie bez znaczenia był tu aspekt osobistego doświadczenia mówcy, co miało bezpośrednie przełożenie na zwieńczenie dyplomatycznej misji Reymonta sukcesem.

Niniejsza edycja nie zaistniałaby, gdyby nie uprzejma pomoc kilku osób. Serdeczne podziękowania zechca przyjąc: dr hab. To masz Pudłocki - za udostępnienie materiałów ze swych amerykanskich kwerend, wsparcie podczas opracowywania rękopisu Reymonta i wreszcie za artykuł, który był katalizatorem moich archiwistycznych poszukiwań; kierownik do spraw kultury Fundacji Kościuszkowskiej - Ewa Zadwórna - za cierpliwość i zrozumienie dla filologicznej dociekliwości; prezes Fundacji Kościuszkowskiej - Marek Skulimowski - za zgodę na publikację i życzliwość dla sprawy; oraz dr hab. Beata U t k o w s k a, prof. Uniwersytetu Jana Kochanowskiego w Kielcach - za lekcję odczytywania duktu Reymontowskiego pisma.

Rękopis Ze strasznych lat 1914-1918 (sygn. KF Accession \# 12.40) znajduje się w zbiorach Fundacji Kościuszkowskiej w Nowym Jorku i stanowi część archiwum jej twórcy - Stefana Piotra Mierzwy (Stephena P. Mizwy) ${ }^{19}$. Niestety, nie udało się ustalić, jaką drogą tam trafił. Przed publikacją tekst został poddany ostrożnej modernizacji językowej i interpunkcyjnej. Działaniom tym przyświecała idea zachowania kolorytu języka epoki oraz idiolektu pisarza. Wspomnienia Reymonta przeznaczone były do wygłoszenia. W tym kontekście istotna wydaje się architektura tekstu, dlatego też pozostawiono oryginalne akapity, nawet jeśli autor postanowił wydzielić tylko jedno zdanie.

\section{ZE STRASZNYCH LAT 1914-1918 WSPOMNIENIA}

[I]

Wojna spadła na Polskę zupełnie niespodziewanie.

Do ostatniej prawie chwili nie wierzono w jej możliwość.

A kiedy się już stała okropnym faktem, jeszcze się łudzono, że niepodobna, aby

19 Precyzyjny opis zasobów archiwum zob. T. Pudłocki, Archiwum Fundacji Kościuszkowskiej $w$ Nowym Jorku. Zapomniana skarbnica dziejów nie tylko nauki polskiej. „Prace Komisji Historii Nauki Polskiej Akademii Umiejętności” 2013. 
mogła trwać dłużej nad trzy-cztery miesiące. Zdawało się bowiem wszystkim, że Europa nie pozwoli na jej dłuższe trwanie.

I wszyscy się mylili, a wszystkie przewidywania zawiodły, bo z przypuszczalnych miesięcy zrodziły się długie i straszliwe lata wojny wszechświatowej. „Człowiek strzela - Pan Bóg kule nosi”. Powiada stare polskie przysłowie.

Przez całą tę krwawą zawieruchę mieszkałem w Polsce, więc pozwolę sobie naszkicować nieco wrażeń i wspomnień $z$ tych lat strasznych.

Nie będzie to historia, ni nawet systematyczny opis zdarzeń, będą to jeno wspomnienia bardzo ogólne i bardzo pobieżne.

Mieszkałem w Zakopanem, w Galicji, kiedy Austria ogłosiła mobilizację swoich wojsk przeciwko Rosji. Było to w ostatnich dniach lipca 1914, pamiętam dobrze ten wieczór pochmurny, zimny i zadeszczony, gdy nakazy mobilizacyjne porozlepiano po rogach ulic. Trwoga ogarnęła wszystkich i długo w noc odczytywano na ulicach ten straszny nakaz przy świetle latarń i zapałek. Płacze wybuchały w nocnych ciemnościach - gorzkie matczyne płacze, zasię do świtania po szynkach pito i śpiewano - pito z rozpaczy i śpiewano z rozpaczy.

Nie dziwota, śmierć tej nocy wybierała już po domach swoje ofiary.

Na drugi dzień pojechałem do Krakowa ${ }^{1}$.

Miasto już było zapchane żołnierzami, a co parę minut pociagi przychodzące ze wszystkich stron wyrzucały wciąż nowe tysiące polskiego chłopa.

Dzień był upalny i suchy, kurz przysłaniał miasto, biwakowano na placach i ulicach pod gołym niebem, rozkładano się pod domami i na podwórzach, a przy dźwiękach wojskowych orkiestr wciąż nadchodziły nowe oddziały wojsk.

Tysiące pijanych wódką, zmęczeniem i zgrozą maszerowało w takt muzyki i ze śpiewami, a co chwila rwał się ze wszystkich piersi potężny okrzyk: Na Moskala! Na Moskala! Aż drżały mury i mocniej biły serca. Kraków był poruszony do głębi, zgorączkowany, prawie nieprzytomny, a ogólny nastrój: austriacko-niemiecki.

$Z$ tej strony spodziewano się zbawienia dla Polski.

Kto nie podzielał tych złudzeń, a miał odwagę nazbyt głośno ostrzegać przed wiarą w Niemców - tego po cichu wywożono do obozu internowanych. Więc aby uniknąc podobnego losu, musiałem spiesznie wyjeżdżać do Królestwa. A trzeba było jechać przez Szląsk, na Katowice, gdyż mosty i koleje na granicy Królestwa i Galicji już były powysadzane w powietrze.

Pojechało nas razem sto kilkadziesiąt osób, przeważnie chorych kobiet i dzieci, uciekających przed wojna, z różnych zagranicznych uzdrowisk. I w Katowicach mieliśmy pierwszą lekcję niemieckiej przyjaźni dla Polaków. Prusacy przyjęli nas niby bandę zbiegłych kryminalistów. Zaraz po wyjściu $z$ austriackich wagonów otoczono nas kordonem i popędzono przez miasto wśród niesłychanych uragowisk. Całe tłumy leciały za nami $\mathrm{z}$ wyciem i przekleństwami. $\mathrm{Z}$ pootwieranych okien

$1 \quad Z$ listu pisarza do M. z Guentherów Maciejowskiej wynika, iż przebywał on w Krakowie od 20 VII 1914 (w: W. S. Rey mo n t, Korespondencja 1890-1925. Oprac., wstęp B. K o c. Warszawa 2002, s. 328). Zob. też B. Ko c, Kronika życia i twórczości Wt. St. Reymonta. Legnica 2007, s. 106: „Wybuch wojny zaskoczył Reymonta na trasie Zakopane, Kraków, Będzin. Gdy przedostał się do Warszawy, został zmuszony do ewakuacji za ustępującymi wojskami rosyjskimi”. 
pluto na nas i rzucano doniczkami. Zdawało się, iż lada chwila ta dzika tłuszcza niemiecka rozszarpie nas pazurami. Chore kobiety omdlewały ze zmęczenia, padały na bruk, nie pozwolono im podać nawet odrobiny wody. Smiertelnie wystraszone dzieci zaczynały płakać, bito je kolbami i kopano, a niemiecki motłoch szalał z radości. Każdy polski jęk i każde polskie cierpienie doprowadzało ich do dzikiego uniesienia i szczęścia.

Prawdziwy to cud, że nas w tej drodze nie pozabijano.

Przedostałem się wreszcie do Sosnowca w Królestwie i stamtąd, uciekając przed pruskimi patrolami, chroniąc się po lasach i kołując, dojechałem do Warszawy. Ale już po drodze szeptali mi ludzie straszne rzeczy o Kaliszu ${ }^{2}$. Nie wierzyłem, ale potem, bliżej Warszawy, zaczałem spotykać całe gromady obdarte, głodne i prawie obłąkane przeżytymi okropnościami. Byli to ci jeszcze najszczęśliwsi, którym się udało uciec z Kalisza, spod pruskich kul, z tego piekła miasta zbombardowanego, spalonego i zrabowanego.

Zniszczenie Kalisza to pierwszy pomnik niemieckiej nikczemności i hańby.

Cała Polska zatrzęsła się od zgrozy, przerażenia i bezsilnego gniewu.

Nie było jednak czasu na biadania, bo wojna zaczynała się przewalać na naszą ziemie niby niszczący, straszliwy huragan. Zdarzenia szły jedne po drugich, jak błyskawice i pioruny wstrząsały światem. Austriackie armie wkroczyły w Lubelskie i rozgrywały się tam pierwsze bitwy ${ }^{3}$, zaś Niemcy szerokim kołem posuwali się $\mathrm{z}$ wolna ku Warszawie.

A każdy z naczelnych dowódców wojsk wkraczających do Polski ogłaszał szumny manifest, w którym przysięgał, że przychodzi oswobadzać nas z carskiego jarzma i pomagać nam będzie do odzyskania wolności.

Czytano te odezwy $\mathrm{z}$ uśmiechem i robiono $\mathrm{z}$ nich odpowiedni użytek.

Nikt im w Polsce nie uwierzył ani na jedną chwilę.

Trzecia, najgłośniejsza z nich odezwa wielkiego księcia Mikołaja Mikołajewicza ${ }^{4}$

2 Niemieckie wojska wkroczyły do miasta 2 VIII 1914. Kalisz był zdobywany, pacyfikowany i plądrowany trzy razy w przeciagu 3 tygodni. Rzeź zakończyła się 22 VIII. Zginęło co najmniej 250 cywilnych mieszkańców Kalisza, ponad tysiąc było rannych, a kilkadziesiąt tysięcy uciekło w stronę Warszawy. W mieście zostało 5 tys. ludzi i bardzo niewiele domów. Gros budynków została zniszczona ogniem artylerii lub spłonęła podpalona przez żołdaków. Najmocniej ucierpiała średniowieczna starówka - przetrwał tam jedynie co dziesiąty dom. Zob. M. D r e w i c z, Wypadki kaliskie 1914. Reinterpretacja obrazu zdarzeń. Kalisz 2014. - W. J arn o, Zniszczenie Kalisza w sierpniu 1914 w świetle polskojęzycznej prasy tódzkiej. „Ces Historica” 2016, nr 42. Wydarzenia te zostały uwiecznione przez M. Dąbrowska w Nocach $i$ dniach (T. 4. Warszawa 1996, s. 387): „Niemcy to wychodzili z miasta, to wkraczali z powrotem, a ile razy wrócili - kończyło się to zawsze wariacką strzelaniną, po której wojsko znów się wycofywało, by zacząc bombardowanie. W chwilach ciszy ludzie wylegali przed bramę jak roje pszczół, śmielsi szli w miasto oglądać szkody wyrządzone przez pociski. Tu trafiło w mieszkanie i zabiło w nim dwoje ludzi, tam leżały na ulicy niepogrzebane trupy, ktoś widział nawet dziecko z głową rozbitą na miazgę".

3 Zapewne chodzi o bitwy pod Kraśnikiem (23-25 VIII 1914) oraz pod Komarowem (26 VIII - 2 IX 1914). Zob. J. Pa je w s ki, Pierwsza wojna światowa 1914-1918. Warszawa 2005. - R. Males zy k, Cmentarze wojenne z okresu I wojny światowej na Lubelszczyźnie. „Annales Universitatis Mariae Curie-Skłodowska” T. 52/53 (1997/1998), s. 253. - Z. W in kle r, Bitwa pod Kraśnikiem 23-25 sierpnia 1914 r. „Głos Ziemi Urzędowskiej” 2014.

4 Po wybuchu pierwszej wojny światowej książę Mikołaj Mikołajewicz Romanow został mianowany głównym dowódcą wojsk rosyjskich. 
ukazała się najpóźniej, bo 12 sierpnia $^{5}$. W szerokich masach sprawiła ona wielkie wrażenie, gdyż Wielki Książę w słowach uroczystych i pięknie stylizowanych obiecywał „zjednoczenie Polski” i „spełnienie się marzeń ojców naszych i dziadów!” ${ }^{\text {Ale }}$ warstwy więcej wyrobione politycznie przyjęły i ten manifest $\mathrm{z}$ niedowierzaniem. I do tego stopnia nie przywiązywano do niej większej wagi, że dopiero w parę dni po jej ogłoszeniu i do tego na specjalne żądania petrogradzkich sfer rządowych ${ }^{7}$ grono ludzi zebranych przygodnie i przeważnie nie zajmujących się polityką przesłało Księciu podziękowanie dość suche i banalne ${ }^{8}$.

Wojna toczyła się swoją nieubłagana koleją.

Niemcy w początkach października tak blisko przysunęli się pod Warszawę, że miasto zadygotało od grzmotu armat, nocami robiło się widno od pożarów, a na placach rozkładały się tysiączne tłumy okolicznej ludności uciekającej przed Prusakami.

Ale odpędzono ich jeszcze na czas jakiś spod Warszawy.

Wrócili dopiero w parę tygodni później nad Bzurę i Rawkę.

Fronty bojowe ustaliły się o 50 wiorst od Warszawy.

Nocami armaty huczały niby dalekie gromy, a w dnie mroźne i słoneczne niemieckie aeroplany zasypywały miasto bombami.

Zginęło wtedy wiele cywilnej ludności i sporo zrujnowano domów.

Ale nastrój tej pierwszej zimy wojennej był jeszcze jaki taki. Fabryki w Warszawie pracowały, handel szedł, zarabiano dużo i łatwo, żywność była bardzo tania,

5 Zob. Odezwa wielkiego księcia Mikołaja Mikołajewicza, głównodowodzacego armii rosyjskiej, do Polaków, wydana $w$ Sankt Petersburgu 14 VIII 1914 r. W zb.: Wiek XX w źródłach. Wybór tekstów źródłowych z propozycjami metodycznymi dla nauczycieli historii, studentów i uczniów. Oprac. M. S obańsk a - B ondaruk, S. B. Len ard. Warszawa 2001, s. 62:

„Polacy! Wybiła godzina, w której przekazane Wam marzenie ojców i dziadów Waszych ziścić się może.

Przed półtora wiekiem żywe ciało Polski rozszarpano na kawały, ale dusza jej nie umarła. Żyła ona nadzieją, że nadejdzie godzina zmartwychwstania dla Narodu Polskiego i dla pojednania się braterskiego $z$ Wielką Rosja.

Wojsko rosyjskie niesie Wam błogą wieść owego pojednania. Niechaj się zatrą granice, rozcinające na częśsi Naród Polski.

Niechaj Naród Polski połączy się w jedno ciało pod berłem Cesarza Rosyjskiego. Pod berłem tym odrodzi się Polska, swobodna w swej wierze, języku i samorządzie”.

Zob. też M. Bobrzyńs ki, Wskrzeszenie Państwa Polskiego. T. 1: 1914-1918. Kraków 1920, s. 13: „Zapowiedziany samorząd pod berłem cesarza rosyjskiego wykluczał przywrócenie państwa polskiego w jakiejkolwiek formie, a mógł być tłumaczony nawet jako samorząd lokalny, bez żadnej terytorialnej autonomii”.

$6 \quad$ Odezwa nie została zatwierdzona przez cara Mikołaja II, dlatego też formalnie nie posiadała żadnej mocy prawnej. Zob. L. B a zylow, Rosja w okresie pierwszej wojny światowej i rewolucji lutowej. Warszawa 1976, s. 128.

7 Piotrogród, późniejszy Sankt-Petersburg, był stolicą Imperium Rosyjskiego w latach 1712-1918.

8 Reymont podpisał skierowany do księcia Mikołaja Romanowa telegram z podziękowaniem, w którym czytamy m.in.: „krew synów Polski, przelewana łącznie $z$ krwią synów Rosyi w walce ze wspólnym wrogiem, stanie się największą rękojmią nowego życia w pokoju i przyjaźni dwóch narodów słowiańskich" (Telegram do Naczelnego Wodza Wojsk rosyjskich Wielkiego Księcia Mikołaja Mikołajewicza. W: K. W. Ku ma ni e c ki, Zbiór najważniejszych dokumentów do powstania państwa polskiego. Kraków-Warszawa 1920, s. 31). Zob. też S. Ta li ko w s k i, Reymont w kręgu rodzinnym. Łódź 1973, s. 82-83. 
złoto było w obiegu, a przy tym jeszcześmy nie zaznali prawdziwych okropności wojny. No i nie czuliśmy się jeszcze w więzieniu, bo otrzymywaliśmy pocztę z zachodniej Europy, a konsulowie państw alianckich jeszcze rezydowali w Warszawie. Zasię Centralny Komitet Obywatelski, jaki powstał w parę tygodni po wybuchu wojny z p.p. ks. Czetwiertyńskim ${ }^{9}$ i Wł. Grabskim na czele, który sprawował niejako rządy cywilne nad pozostałą częścią Królestwa, rządził tak sprężyście, czujnie i mądrze, że jeszcze tej zimy nikt nie zaznał głodu, zimna i nędzy.

Tak ciagnnęło się do wiosny $1915 \mathrm{r}$.

Dopiero przerwanie rosyjskiego frontu pod Gorlicami ${ }^{10}$ pokazywało nam jasno, że Moskale będą zmuszeni do wycofania się i z reszty Polski. Wprawdzie władze rozgłaszały, że ani myślą o porzuceniu kraju, i Warszawy będą bronili do ostatka. Jednak w początkach czerwca zaczęli się dość pospiesznie wynosić. Codziennie setki automobilów wywoziło $\mathrm{z}$ Warszawy na dworce kolejowe prowadzące do Rosji ruchomości rządowe i rodziny urzędników.

Z cichą, ukrywaną radością wyczekiwaliśmy na ich generalną ucieczkę. Ale niestety tę radość psuła nam bliskość Prusaków. Bo i cóż że jeden wróg pobity ucieknie, kiedy drugi, może jeszcze straszniejszy, już czeka pod murami. Rosła też w mieście trwoga, znerwowanie i niepokój, zwłaszcza kiedy zaczęto wywozić fabryki pracujące dla wojska i wraz z nimi tysiące robotników, majstrów i inżenierów. Potem nawet już same władze zaczęły jawnie namawiać do wyjazdu do Rosji. Dawano każdemu, kto zażądał, zapomogi na drogę. Policja rozdawała bezpłatne bilety kolejowe, radzac każdemu, niby to $z$ dobrego serca, żeby uciekał przed Niemcami. Wreszcie wszystkim wielkim fabrykantom, kupcom i znanym obywatelom nakazano wyjeżdżać do Rosji. Książę Engałyczew ${ }^{11}$, ówczesny generał-gubernator, powiedział publicznie, że pozostanie w Warszawie sama „swołocz” ${ }^{12}$, a wszyscy porządni ludzie wyjadą $z$ nim razem. Niestety, te nakazy zrobiły swoje, a strach dokonał reszty i dużo ludzi wyjechało, szukając w Rosji ocalenia. Niemało przyczynił się do tych ucieczek i rozgłos niemieckich znęcań się nad ludnością okupowanych przez nich części Francji i Belgii.

A przy tym wszyscy myśleli, że za jakiś miesiąc lub dwa będą z powrotem.

Moskalom jeszcze nie było tego dosyć.

Bowiem w poczatkach lipca 1915 wydali głupi, potworny i dziki rozkaz swoim wojskom, aby przy cofaniu się przed Niemcami niszczyły za sobą wszystko i ludność uprowadzały ze sobą.

Tylko ciemny a fanatyczny mózg moskiewskiego satrapy mógł się zdobyć na ten piekielny pomysł. Myśleli, że jak spalą i zniszczą, jak cały kraj przemienią w pustynię, jak wszystką ludność uprowadzą, to Niemców powstrzymają na czas dłuższy.

I natychmiast zabrali się do wykonania okropnego pomysłu.

Seweryn Franciszek Ś w i a t o p ełk - C z e t w e r ty ń s k i (1873-1945) - polityk, ziemianin, działacz społeczny, Wicemarszałek Sejmu.

10 Tzw. front rosyjski został przerwany pod Gorlicami podczas walk między 2 a 5 V 1915.

11 Pawieł Nikołajewicz J e n gał y c ze w (1864-1944) - pochodzący z arystokratycznego tatarskiego rodu rosyjski generał. W grudniu 1914 został generałem-gubernatorem warszawskiego okregu wojskowego. Pełnił tę funkcję na zmianę z księciem Nikołajem Tumanowem.

12 
Tysiące Kozaków rzuciło się na kraj: jedni pędzili z zapalonymi żagwiami, żeby podpalać domy i zabudowania; drudzy mieli niszczyć zboża po polach, wycinać sady i zasypywać studnie, a reszta miała wszystką ludność wypędzać z pogorzelisk i gnać stadami do Rosji.

Było to w początkach lipca, zboża właśnie dojrzewały i żniwa zapowiadały się wyjątkowo świetnie, gdy naraz, pewnej nocy zarumieniło się niebo od pożarów, zahuczały ponuro dzwony na trwogę i krzyk rozpaczy zatargał powietrzem, bo już tu i ówdzie paliły się wsie, niszczono zboża, zabijano bydło i ludność tysiącami wypędzano $z$ prawiecznych siedzib.

Zdawało się, że już nie ma ratunku i cały kraj pójdzie w ruinę.

Władze na wszystkie prośby i błagania pozostały głuche.

Na szczęście „łapówka” ocaliła choć częściowo tragiczną sytuację. Moskiewskie dusze są bardzo czułe na „wziatki” ${ }^{13}$. Więc gdzie Kozakowi wetknięto w łape parę rubli, czasem zaledwie kilkadziesiąt kopiejek, a w dodatku jeszcze poczęstowano gorzałką - tam ruble brał, gorzałkę wypijał, życzył szczęścia i dawał spokój całym wsiom i gminom. A gdzie nie pomogły takie argumenta, tam chłopi dragami i cepami bronili swojego dobra. W wielu miejscach dochodziło do formalnych bitew, w których niejednego zatłuczono Kozaka. Tak było w bliższych i dalszych okolicach Warszawy, ale nad Bugiem, prawie w całej Chełmszczyźnie i częściowo w Guberniach Lubelskiej i Łomżyńskiej, na szlakach, którymi cofały się armie rosyjskie i gdzie toczyły się zacięte bitwy, tysiące wsi zostało spalonych i zrównanych z ziemią, a setki tysięcy ludu popędzono przed wojskami na śmierć, nędzę i zatracenie.

Cały tamten kraj przemienił się w dziką, głuchą pustynię.

$\mathrm{A} \dot{z}$ nareszcie wybiła ostatnia godzina moskiewskiego panowania w Polsce. Przyszła ta historyczna noc: noc z 4 na 5 sierpnia 1915 r. ${ }^{14}$

Cały ten ostatni dzień czwartego sierpnia armaty nie przycichały ani na chwilę, klekotały coraz bliżej mitraliezy ${ }^{15}$ i nieustannie grzmiały karabinowe salwy. Miasto się trzęsło od huków. Ulicami przelatywały galopem baterie armat, długie tabory, szpitale i nieprzeliczone automobile, i chłopskie wozy. Oddziały wojsk z najeżonymi bagnetami płynęły niby wezbrane rzeki do mostów na Wiśle. Miasto było w goraczce, reszta fabryk stanęła, pozamykano sklepy i bramy domów, pozasłaniano okna i kto jeno żył, wychodził na miasto. Niepodobna było wysiedzieć w domu. Na ulicach było pełno ludzi. Z przerażeniem przyglądano się maszerującym wojskom.

W powietrzu czuć było zbliżającą się katastrofę.

Pomimo tego jeszcze powszechnie nie wierzono w ucieczkę Moskali.

Bowiem pozornie, na oko, wszystko było jak zawsze: po rogach ulic stali policjanci, kozackie patrole krążyły po mieście, a „ochrana”16 łowiła po mieście „niebłagonadiożnych"17 jak co dzień, jak przez dziesiątki lat.

„Wzjat” (ros.) - wziąć, pobrać.

5 VIII 1915 niemieckie wojska wkroczyły do Warszawy. Zob. M. E c k e r t, Historia Polski 1914-1939. Warszawa 1990. - Pajews ki, op. cit.

Mitralieza - szybkostrzelne działko.

Ochrana - tajna policja rosyjska, która powstała z rozkazu cara Aleksandra III w 1881 roku.

„Błagonadieżnyj” (ros.) - godny zaufania. W Rosji carskiej „błagonadiożnym” wydawano zaświad- 
A tymczasem generał-gubernator wyniósł się za Wisłę i zamieszkał w pociagu, a władzę nad Warszawą objął Komitet Obywatelski ${ }^{18}$.

No i Żydzi mieli radosne, tryumfujące twarze $-\mathrm{z}$ niecierpliwością wyczekiwali wkroczenia swoich protektorów Prusaków.

O zmierzchu ścichły nagle strzelaniny, noc zapadła ciemna, bez gwiazd, trwożna i rozdygotana śmiertelnym niepokojem.

Tylko gdzieniegdzie paliły się latarnie.

Czarne, nieoświetlone domy wynosiły się w ciemnościach niby góry.

Robiło się strasznie, lęk ogarniał najodważniejszych.

Szeptano sobie na ucho jakby przy łożu konającego.

Przed kościołami modliły się całe tłumy.

A to głuche i nagłe milczenie wielkiego miasta przejmowało dziwna trwogą. Coraz potworniejsze plotki krążyły z ust do ust: szeptano, że Moskale miasto wysadzą w powietrze, że Kozacy lada chwila zaczną rabować i wyrzynać, że wodociągi i elektrownia już zniszczone. Przerażenie wzbierało $z$ minuty na minutę, a czas przechodził w tych oczekiwaniach strasznie wolno, godziny zdawały się być długie jak lata. Nie można się było doczekać jakiegoś końca.

Owo tymczasem resztki wojsk moskiewskich uciekały coraz prędzej.

Widać było w ciemnych ulicach jeno zbite i pomieszane ze sobą wszystkie rodzaje broni, jak płynęły w jedną stronę, płynęły nieprzerwaną, czarną falą ludzi, armat, koni, ambulansów i taborów.

A jeszcze ostatnie oddziały mrowiły się na Placu Zamkowym, przed mostem, kiedy już na Pradze, za Wisłą, zaczęły wybuchać olbrzymie pożary!

Moskale podpalali wszystkie gmachy i budynki rządowe.

Paliły się wielkie dworce kolejowe! Paliły się składy monopolowe wódki ${ }^{19}$. Paliły się zbiorniki nafty! I paliły się olbrzymie składy wojskowej intendentury! Podpalono również kolosalne składy węgla należące do kolei ${ }^{20}$.

Krwawe morze płomieni zalało całą Pragę i w tych strasznych brzaskach Wisła zdawała się spływać żywą, człowieczą krwią.

Grozę podnosiły jeszcze nieustające grzmoty wysadzanych w powietrze domów, tunelów, wiaduktów i kolejowych warsztatów, i różnych urządzeń.

O świtaniu zobaczyłem, jak uciekała $z$ Warszawy reszta policji i żandarmerii moskiewskiej. I widziałem, jak wielu $z$ nich rzewnie płakało.

Zaraz po szóstej rano wyleciały w powietrze wszystkie cztery mosty na Wiśle.

Moskali już nie było w Warszawie.

Lecz nie opadły jeszcze dymy wybuchów i pożarów, kiedy zawarczały bębny, zaświstały klarynety, zagrały ponuro trąby i hordy niemieckie zaczęły mocnym, twardym, zwycięskim krokiem zalewać miasto.

czenia o nieuczestniczeniu w antyrządowej działalności. Było to potrzebne podczas ubiegania się o pracę czy w trakcie podróży.

Centralny Komitet Obywatelski w Warszawie (CKO) - organizacja społeczno-gospodarcza utworzona w 1914 roku za zgodą władz rosyjskich.

20 Być może, chodzi o zasoby, które znajdowały się w okolicach ulicy Tunelowej. Zob. A. Pa s zke, Dworce Drogi Żelaznej Warszawsko-Wiedeńskiej. Oddział I, Warszawa-Skierniewice 1845-1920. Warszawa 1986, s. 11-12. 
Mieliśmy nowych panów.

Żydzi szaleli ze szczęścia, witając Prusaków kwiatami.

A Komitet Obywatelski, nie zważając na nową okupację, tak sprawował swoje rządy, że od świtania już milicja miejska zajęła posterunki na ulicach, a sądy polskie rozpoczęły swoje czynności o godzinie 10 rano.

Zaczęły się zgoła nowe i niewypowiedzianie ciężkie czasy.

Czasy, jakich nie przewidywali nawet najposępniejsi pesymiści.

Całe lata powolnej męki i powszechnej ruiny.

Po zajęciu Warszawy Niemcy wydali manifest do narodu, w którym pisali, że wchodzą do Polski jak przyjaciele, że prywatna własność będzie uszanowaną, że będą się rządzili tylko prawem i sprawiedliwością, że przychodzą nas oswobadzać spod tyranii caratu! ${ }^{21}$

I tak święcie spełnili swoją uroczystą obietnicę - że pod koniec ich panowania w Polsce dziesiątki tysięcy polskich robotników, przemocą wywiezionych do Niemiec, ginęło z głodu i nadmiernej pracy, tysiące marło w obozach jeńców i po więzieniach, a po miastach polskich już nawet brakowało trumien dla pomarłych z głodu - chowano ich w starych skrzyniach, po paru nieboszczyków razem, i pookręcanych, w braku odzienia, w papierowe prześcieradła.

Spadli na Polskę niby stado zgłodniałych wilków.

I nażerali się naszym kosztem do syta!

Dzieci nasze po miastach marły tysiącami z braku mleka, bo Niemcy nakazali dostawiać sobie po parę funtów masła tygodniowo od każdej krowy. A kto śmiał nie dostawić, płacił wysokie kary, a w dodatku brał kije od żandarmów. Na Podlasiu zaś i w całym Ober-Oście pozostającym pod wojskowym zarządem zaregestrowali wszystkie kury po wsiach i od każdej musieli dostarczać im po pięć jajek tygodniowo. Mało tego, przecież na Kujawach, w bliskości kolei, niektórym gminom landraci $^{22}$ nakazywali dostawiać na stację po furze nawozu z każdej morgi.

Wywozili go do Prus.

Wywozili też ze wschodniej Galicji, nawet czarnoziem całymi pociagami na swoje brandenburskie piaski.

Ale odbiegłem od porządku, niechaj mnie wytłumaczy okropność wspomnień. W Warszawie rozpoczęli swoje rządy po swojemu, tzn. obiecywali złote góry, mieli

Zob. Odezwa do Polaków Naczelnego Dowództwa niemieckich i austro-węgierskich armii wschodnich z poczatku sierpnia $1914 \mathrm{r}$. W zb: Wiek XX $w$ źródłach, s. 61:

„Polacy!

Zbliża się chwila oswobodzenia spod jarzma moskiewskiego.

Sprzymierzone wojska Niemiec i Austro-Węgier przekroczą wkrótce granicę Królestwa Polskiego. Już się cofają Moskale. Upada ich krwawe panowanie, ciążące na Was od stu przeszło lat. Przychodzimy do Was jako przyjaciele. Zaufajcie nam!

Wolność Wam niesiemy i niepodległość, za którą tyle wycierpieli ojcowie Wasi.

[...] Z naszymi sztandarami przychodzi do Was wolność i niepodległość”. 
na ustach: prawo, sprawiedliwość, a rządzili gwałtem i grabieżą, zwłaszcza iż znaleźli w Żydach wiernych i pojętnych sprzymierzeńców.

Nawet w drobniejszych sprawach pokazali się ordynarnymi oszustami.

Na własne oczy widziałem zbiór kwitów, jakimi płacili z początku za rekwirowane bydło i zboże po wsiach.

Na jednym $z$ nich, zamiast wyszczególnienia, co zabrano i na jaką sumę, napisano: „Idź, głupi, do Moskali, niech ci zapłacą”. A na drugim: „Niech żyje Wilhelm II”. A na trzecim: „Okazicielowi tego kwitu dajcie kamraci w pysk”. I zamiast podpisów, kładli jakieś nieczytelne zygzaki.

Naturalnie kwity były pisane po niemiecku, chłop brał je w dobrej wierze, bo nie rozumiał, a przy tym wystawiali je wspaniali oficerowie niemieccy!

$Z$ powodu tych bezwartościowych kwitów przyszło do ciekawej sceny w jednym ze dworów w Rawskiem. Jakiś oficer zarekwirował we dworze kilkanaście krów, wybrał co najlepsze konie, wozy, uprzęże i oceniwszy wszystko śmiesznie nisko, napisał kwit formalny i dał go właścicielowi.

- Po cóż takie ceregiele, kiedy i tak mi nie zapłacicie! - powiedział dziedzic.

- Jak pan śmie tak mówić, to obraza Niemiec, my zawsze i święcie wypełniamy nasze zobowiazania, niemiecki podpis to złoto! - zawrzesz[cz]ał oficer.

- Szkoda tylko, że za takie złoto nie można kupić sobie nawet postronka! - odpowiedział szlachcic zuchwale i wydobywszy z biurka plikę starych, pożółkłych papierów, podsunął je pod nos rozwścieczonego Niemca.

- Oto kwity niemieckie $\mathrm{z}$ roku pańskiego 1794, za rekwirowane w tym samym majątku bydło, konie i owce! Suma złotych polskich 37.500! Niezapłacone! A to kwity z roku 1797, również za bydło, siano, zboże itp. Niezapłacone!

- Pan jesteś wrogiem Niemiec! Zakrzyczał oficer i wyjechał rozgniewany.

To, co przytaczam, to jeno mała próbka niemieckiej uczciwości.

Chłopi pomiarkowawszy wnet, co znaczą niemieckie kwity i niemiecka uczciwość, zaczęli wszystko chować, jak się tylko dało. Niemcy wydzierali im siła, podstępem, biciem i sadzaniem do więzień. A przy tej bezecnej robocie ograbiania i rozbojów, Żydzi byli najżarliwszymi pomocnikami, bez ich pomocy Niemcy nie byliby w stanie dokonać ani w połowie tych złodziejstw. Wobec tego, od pierwszych dni okupacji, zawrzała cicha, sroga i nieubłagana wojna - wojna uzbrojonych rabusiów $\mathrm{z}$ bezbronną polską ludnością.

A Niemcy, gnębiąc i rabując, nie przestawali wciąż obiecywać wolnej Polski, nie przestawali łudzić na wszystkie sposoby! Kto chciał i komu to było na rękę, uwierzył. Naród nie dał się jednak okpić fałszywymi obiecankami! Naród prędko odczuł, że cokolwiek Niemcy mówią, cokolwiek obiecuja, na cokolwiek przysięgaja - to wszystko kłamstwo, zdrada i pozór, gdyż prawdziwym ich celem jest zniszczenie Polski...

I ten instynkt ocalił nas od zguby.

A przecież i własnych, polskich kusicieli nie brakowało w te dnie:

- Byli, którzy przysięgali na Franciszka Józefa i wołali, że tylko z Austrią nasze szczęście i przyszłość; - byli, którzy w Berlinie wyprzysięgali się Poznańskiego i jeno w łączności z Prusakami widzieli polskie jutro; a najliczniejsi może byli ci, którym było pilno do posad, robienia dobrych interesów i wystawania w cesarskich przedpokojach, zasię wszyscy jednako krakali: Niemcy są niezwyciężeni! Niemcy są 
najmędrsi, bo sa najmocniejsi. Trzeba się wyrzec mrzonek i zapomnieć o Poznańskiem, zapomnieć o Gdańsku, zapomnieć o Szląsku i pruskich Mazurach! Byle pozyskać chociaż pozór, chociaż cień samodzielności, chociażby na najmniejszym skrawku Polski! Gotowi byli się zgodzić na Polskę tak okrojoną i małą, żeby nam w niej starczyło miejsca akuratnie na wspólny grób!

I to jest wiekopomna zasługa ludu, że z pogardą odrzucał te wszystkie kuszace głosy. Zdrowy, piastowski instynkt przemówił w duszach i $z$ wolna nieśmiertelne Kościuszkowskie hasło: „Wolność! Całość i Niepodległość”, stawało się hasłem całego narodu!

I nie mogło być paktów ze śmiertelnym wrogiem, każdy bowiem pojmował, że albo my, albo oni! Wyboru nie było i wahać się nie było wolno.

Na próżno też te różne orientacje polityczne wrzeszczały błagalnie:

„Warszawo, przemów!”

Na próżno przyjeżdżały całe tuziny „wielkich” polityków krakowsko-wiedeńskich i ze łzami w oczach, wyciagając błagalnie ręce, wołały:

- „Warszawo przemów!”

Na próżno również przyjeżdżały socjalistyczno-żydowskie ekscelencje z Krakowa i na wiecach, wobec tysięcy ludzi, krzyczały, że „Polska niby bluszcz obwinie się koło tronu Habsburgów i trwać będzie w takiej szczęśliwości na wieki”.

Warszawa milczała.

Nazwano ją za to prostytutką, hańbą Polski, podłą niewolnicą cara!

Narodu nie mogą dotknąć takie obłąkańcze obelgi, a Warszawa przemówiła dopiero w dniach listopadowych, gromiąc i wypędzając Niemców; przemówiła głosem gromów i przemawia dotychczas jeszcze, walcząc na wszystkich frontach z nieprzyjacioły za „Całość, Wolność i Niepodległość”.

Wobec takiego oporu Warszawy i Królestwa Niemcy zabrali się do roboty nękania i wyniszczania $z$ największą systematycznością.

Zawrzała nieubłagana walka na śmierć i życie.

Przede wszystkim zaprowadzili w całej okupacji przymus pasportowy ${ }^{23}$.

Pod srogimi karami nie wolno było wyjść nawet przed dom bez pasportu, a niezależnie od tego nie wolno było wyjść $z$ miasta za rogatki, $z$ gminy do gminy, ze wsi do wsi bez specjalnych przepustek wydawanych tylko na parę dni, naturalnie za opłata osobna, po 2 i 3 marki od osoby. A jeśli kto musiał jechać koleją, wyrobić był powinien nowe pozwolenie i znowu za nie zapłacić. Jechać zaś było tylko można w najgorszych wagonach, na których wisiały tabliczki $z$ napisami: „dla krajowców”24. Za samo prawo kupienia sobie biletu do drugiej klasy płaciło

Obowiązek ten został wprowadzony zarządzeniem H. H. von Beselera z 9 IX 1915. Zawierało ono 10 szczegółowych punktów. Jeden z nich brzmiał: „Kogo napotka się bez paszportu albo kto nosić będzie przy sobie niewłaściwy, fałszywy lub sfałszowany, lub w ogóle nieważny paszport, karany będzie więzieniem w domu karnym do 10 lat lub, przy przyznaniu okoliczności łagodzacych, więzieniem do 5 lat albo grzywną od 10 do 6000 marek" (Rozporzadzenie dotyczace zaprowadzenia powszechnego przymusu paszportowego. „Dziennik Rozporządzeń” 1915, nr 2, s. 1). Zob. też Wojna z musu. „Dziennik Narodowy” 1915, nr 104, s. 1. 
się trzy marki, pod formą świadectwa „odwszenia” wydawali je specjalni doktorzy, Niemcy.

Nałożyli ogromne podatki, a dawne, niezapłacone Moskalom, ściagali wojskowymi egzekucjami. Kto nie mógł zapłacić, tego bez litości licytowano choćby do ostatniej poduszki spod głowy, do ostatniego łacha.

Zasekwestrowano wszystkie towary i surowce po sklepach, składach i fabrykach.

Zabrano wszystkie lepsze konie $\mathrm{z}$ całego kraju.

Zaś po wsiach zarówno chłopom, jak i większym właścicielom nie wolno było sprzedawać ani ziarna zboża, ani krowy, ani jaja, ani nawet snopka słomy - bo Niemcy zabierali wszystko po z góry oznaczonych cenach i płacili kwitami. Nie dość tego, ale naznaczyli jeszcze $z$ każdej morgi ziemi uprawnej taką ogromną ilość ziarna, słomy, ziemniaków, siana i funtów mięsa, które musiano odstawiać do niemieckich magazynów po powiatach, że już w pierwszym roku okupacji, na wiosnę 1916 r., głód zajrzał do miast i wsi polskich.

Nie było co jeść, ni czym zasiać, ni czym zorać pól!

A w dodatku, wolno było prowadzić handel produktami rolniczymi, tylko rządowej spółce berlińskiej, naturalnie żydowskiej.

Proszę więc sobie wyobrazić, jakie musiały dziać się nadużycia i jakie nowe krzywdy spadały na nieszczęśliwą ludność, zwłaszcza iż ten przymusowy handel odbywał się pod opieką pruskich żandarmów i bagnetów. Właściwie były to zbrojne egzekucje po wsiach i dworach i systematyczny rabunek koni, krów, zboża, trzody chlewnej i nawet wozów!

A później, jesienią, kiedy wojska niemieckie zaległy bojowe pozycje w głębi Litwy i Białorusi, a rozpoczęła się wczesna zima, zaczęli po wsiach zabierać chłopom kożuchy i co lepsze buty, i koszule!

Ściagali z kobiet wełniaki, zabierali płótna domowej roboty, zabierali gotową do tkania przędzę, zabierali wełnę, zabierali uprzęże, zabierali skóry, zabierali nawet stare worki.

Ustanowili normę pożywienia dla każdego człowieka, a jeśliby przy rewizjach znaleźli choć parę łutów ${ }^{25}$ mąki, więcej niźli było przepisane, konfiskowali.

A jeśli jakiś zuchwalec ośmielił się bronić ostatniej krowiny, żywicielki swoich dzieci - zabijali go bez miłosierdzia jako wroga Niemiec i buntownika.

A jeśli u kogo znaleźli jakąś prawieczną strzelbę - zabijali za taką zbrodnię. A jeśli kogoś denuncjowano, że przechowuje u siebie dawnego żołnierza rosyjskiego, chociażby to był syn rodzony - zabijano również na mocy prawa wojennego. Za byle co, za niesłuchanie drakońskich rozkazów, za niedostarczenie naznaczonego kontyngentu, za nieustapienie $z$ drogi niemieckiemu parobowi - całe gminy, całe wsie i miasteczka płaciły dziesiątki tysięcy marek kary, a setki ludzi pędzono w kajdanach do więzień, wywożono do Niemiec na przymusowe roboty lub zamykano do obozów jeńców, gdzie marli z głodu i tyfusów.

W krótkim też czasie Polska wieś przybrała pozór smętarzyska; ludzie chodzili jak cienie, ze strachem wyglądając każdego nowego jutra. Pomilkły śpiewy i muzyki, ogłuchły domy, opustoszały drogi, bo wszędzie Żydzi na służbie niemieckiej 
węszyli, nasłuchiwali i donosili. Pruscy zaś żandarmi kwaterowali w każdej gminie i miasteczku, że niepodobna się było ruszyć w całym kraju, żeby się nie natknąć na pikielhaubę ${ }^{26}$, bagnet nastawiony i oczy zbójecko penetrujące.

Ołowiany i ciężki smutek pokrył Polskę jakby posępną mgłą, lecz w sercach narastała zawzięta, nieprzebłagana nienawiść do Niemców. I uczono kryć się przed rabusiami ze wszystkim, co mogli zabrać i ukraść.

Chowano więc krowy po lasach, a zboże zakopywano w ziemi.

Był taki wypadek. W Miechowskiem, przy granicy dawnej Galicji, jeden z polskich legionowych oficerów, któremu polecono spisać wszystkie groby żołnierzy padłych w bojach, jakie się toczyły w tamtych okolicach, znalazł pod jedną wsią mały cmentarz i kilkanaście mogił starannie odarniowanych, na każdym $z$ nich był krzyż prawosławny i rosyjskie napisy! Zdziwił się, gdyż w jego spisie nie było żadnej wzmianki o bitwie czy utarczce pod tą wsią. Woła sołtysa.

- Co to za mogiły? - pyta, niczego nie podejrzewając.

- Żołnierzy, panie kapitanie, niby to Rusków... Odpowiedział chłop spokojnie.

- Nic nie wiem o bitwie tu stoczonej, kiedy to było?

- Kiedy? A jakoś wtenczas, kiedy to Moskale szli na Kraków. Sroga tu była bitwa! Strzylali, że aże strach! Dużo trupa padło, dużo krwi się polało. Gadał sołtys i gadał tak długo, i rozwodził się tak szczegółowo, i tak udowadniał stoczoną bitwę, aż oficer zaczął mimo woli coś podejrzewać.

- Trzeba będzie rozkopać mogiły, to się dowiemy, do jakich wojsk należeli zabici.

- Wszystkie tu były, panie; piechota i konnica, i ci od armat, i Kozaki.

- Zobaczymy! Zwołać kilkunastu ludzi z łopatami. - Rozkazał oficer.

Sołtys poszedł, ale wrócił prawie $z$ całą wsią i wszyscy $z$ dragami.

- Grobów ruszać nie można, bo tam leżą i ci co pomarli na cholerę - wyrecytował sołtys występując naprzód. - Choroba rozniesłaby się na okolicę!

- Nie damy ruszać grobów! Nie pozwolim! Zaczęli groźnie pokrzykiwać.

Wtedy oficer zrozumiał i zaczął się serdecznie śmiać.

- No dobrze, nie ruszę tych mogił i nie powiem nikomu, możecie mi wierzyć i przeczytawszy napis na pierwszym krzyżu z brzega, powiedział - Iwan Petrowicz Iwanow, czego pilnuje? Mówcież otwarcie, widzicie, że wiem wszystko.

- To Jasiowa pszenica i parę korczyków żyta! Odpowiedział z uśmiechem sołtys.

- A ten drugi, Paweł Antonowicz Łykow, cóż on kryje?

- To moje, panie kapitanie, tam jeno skrzynia $z$ babskim przyodziewkiem i worek mąki, worek kaszy i trochę przędzy! Musielim tak pochować, bo już tak te Austryjaki kradły, tak zabierały wszystko, że jeszcze miesiąc albo dwa i sami byśmy zdechli z głodu. Poszlim po rozum do głowy i zakopalim. Już tu wielu pytało o tych zabitych! I niejeden pacierz odmówił za pozabijanych! I nikomu ani postało w myśli podejrzenie, dopiero p. kapitan...

Opowiadał mi to ów kapitan, nie zdradziwszy jednak nazwiska owej wsi.

Tak się bronili po wsiach przed zbrojnym rabunkiem niemieckich hord.

Zasię po miastach było może jeszcze gorzej.

Niemcy potrzebowali robotników do swoich wojennych fabryk i na rolę, której 
nie miał kto uprawiać. Zaczęli więc po wszystkich wsiach, gminach i miastach ogłaszać, aby się zgłaszali robotnicy na wyjazd do Niemiec, obiecujacc przy tym niesłychane zarobki, przejazd darmo, opiekę sanitarną i powrót wtedy, kiedy się każdemu będzie podobało.

Ludzie czytali te ogłoszenia skwapliwie, boć w kraju roboty nie było, ale że nie bardzo wierzono w te obietnice, nikt się nie kwapił jechać do Niemiec. Wtedy Niemcy postanowili głodem przymusić ich do uległości.

Zamknięto więc resztę fabryk, wywieziono maszyny, pozabierano transmisyjne pasy, a co pozostało, porozbijano i zniszczono.

Robotnicy się nie poddali, chociaż już głód zaczął do nich zaglądać.

Wtedy zabroniono miastom wydawania zapomóg bezrobotnym, zabroniono nawet ich rodzinom wydawać darmowe obiady.

Nędza zaczęła się szerzyć i kto jeno miał do kogo, uciekał na wieś przed śmiercią głodową! Do Niemiec jednak nie chcieli wyjeżdżać.

Wówczas Niemcy wzięli się na inny sposób; oto zaczęli polować na robotników niby na dzikie zwierzęta. Po ulicach Warszawy patrole łowiły młodych i zdrowych ludzi. Wywozili ich do Niemiec. Robili obławy po miastach fabrycznych jak w Łodzi, Pabianicach, Zgierzu i Zduńskiej Woli. Napadali w czasie jarmarków i wybrawszy co najtęższych, wywozili. Czyhali na różne wiece i zebrania robotnicze, żeby wpaść zbrojnie i pochwyconych popędzić w kajdanach na ciężkie roboty do Niemiec. W ten sposób, podły i podstępny, zabrali dziesiątki tysięcy. Ten rabunek ludzi trwał tak długo i uporczywie, aż wielu, znękanych nędzą i ukrywaniem się przed żandarmami, poszło dobrowolnie. I niewielu $z$ nich powróciło, zjadła ich tam niewolnicza praca nad siły i głód. A żony i dzieci pozostałe w Kraju na próżno wyczekiwały od mężów i ojców przyobiecanej pomocy. I na próżno całymi tygodniami cisnęły się po różnych niemieckich urzędach, żeby się chociaż dowiedzieć, czy aby żyją.

Większość przepadła jak kamień we wodzie.

I nie koniec na tych rabunkach mężczyzn, były jeszcze straszniejsze.

Owo na Podlasiu i w tak zwanym Ober-Oście wybierali Niemcy po wsiach niektórych co najpiękniejsze dziewczyny i mężatki, i pod pozorem, że potrzebują po miastach żeńskiej usługi, wywozili je dla armii walczącej na froncie rosyjskim. Przebrała sie jednak chłopska cierpliwość, odbili transporty, dochodziło do krwawych rozpraw i rzezi! Nie pozwolili jednak, a potem kiedy jaki bądź żołnierz zbliżał się do wsi, to wszystkie kobiety chowały się, gdzie tylko mogły, jak kiedyś przed napadami Tatarów.

Nic też dziwnego, iż prócz nienawiści i nędza rosła $z$ dnia na dzień po miastach i miasteczkach. Wszystko też drożało w niepojęty sposób i głodowa śmierć jęła zaglądać w oczy milionom ludzi. W kraju zaczynało brakować wszystkiego, a musiało brakować, gdyż Niemcy rabowali, co im tylko wpadło w pazury, resztki zaś wykupywały za wielkie ceny spekulanckie hieny na wywóz do Prus.

Rekwirowali w całym kraju samowary i rondle, miedziane wanny i cynkowe dachy, klamki mosiężne i okucia. Rekwirowali włókniste towary. Zabierali stolarzom suche drzewo, kowalom zapasy żelaza, szewcom i garbarniom skóry! A gdzie mogli, to nie darowali i prywatnym mieszkaniom - meble, dywany, fortepiany i pościele szły całymi pociagami do Berlina jako łup wojenny.

Nawet mosiężne kable od tramwajów i telefonów wypruli z ulic Warszawy i Łodzi. Nie darowali również kościelnym dzwonom i metalowym sprzętom. 
Zabierali nawet łozinę do wyrobu koszyków i wywozili ją do Niemiec.

Kraj też wpadał w otchłań ostatecznej nędzy.

Miasta literalnie marły $z$ głodu.

Nawet chorym po szpitalach nie było co dawać jeść i zbrakło lekarstw.

Ludzie też marli jak muchy, zwłaszcza zaś dzieci. Zabroniono je wywozić na cmentarze w dzień, żeby nie wywoływać wzburzenia, więc jeno o zmierzchach posuwały się ciemnymi, wyludnionymi ulicami nieprzeliczone karawany białych trumienek, wieźli je ojcowie na wózkach lub matki dźwigały na plecach. I tak trwało całe miesiące i całe lata.

A i Warszawa zaczynała być podobna już więcej do smętarza niźli do miasta. Większość mieszkańców w zimowych miesiącach obywać się musiała bez światła i opału. Kwarta ${ }^{27}$ nafty kosztowała czterdzieści marek, a pud ${ }^{28}$ węgla siedem. Domy stały ciemne, ulice były puste i latarnie niezapalone, że tylko tu i ówdzie tliło się w ciemnościach jakieś światełko.

Ale domy zajęte przez Niemców, wszystkie ich koszary i urzędy, gorzały całe noce jarzącymi światłami, a wewnątrz aż dusili się od gorąca. Sobie nie żałowali niczego. Przecież dobrze i wesoło żyli na nasz koszt. Warszawie brakowało pieniędzy na utrzymanie szpitalów, na szkoły, na konieczną pomoc konającej z głodu ludności, bo musiała utrzymywać całe hordy niemiecko-żydowskich urzędników, musiała utrzymywać liczną załogę, płacić hotele za oficerów, meblować im mieszkania i dawać na każde żądanie władz setki tysięcy i miliony na ich potrzeby. A kiedy na radzie miejskiej podnosić się zaczęły głosy protestów, to wywieziono oponentów do Niemiec, żeby się tam w strasznych obozach jeńców nieco uspokoili.

Wolno tylko było cierpieć, płacić, oddawać, czego żądano, i milczeć.

A dla swoich przyjaciół politycznych i adherentów stworzyli „Radę Tymczasowa”"29. Prawdziwy teatr marionetek i pajaców, poruszany sznurkami, z Berlina i Wiednia. Prawdziwą karykaturę rządów, śmieszną i zarazem tragiczną.

Było ciężko, gorzej, niżeli jestem w stanie opowiedzieć, a już te niekończące się, długie miesiące zimowe bez światła i opału stawały się nie do wytrzymania. Wypijały $\mathrm{z}$ nas życie niby legendarne wampiry.

Przed sklepami Komitetu Obywatelskiego majaczyły dniami całymi i nocami nieskończone ogony - otwierano je o siódmej rano, a już od północy, często nawet i zaraz z wieczora, zbierali się pod nimi, wyczekując swojej kolei.

Szły trzaskające mrozy, lodowate wichry, do kości przejmujące jesienne deszcze i wichry, a kobiety, dzieci i starcy ledwie przyodziani, w łachmanach, z nogami pookręcanymi tylko w stare gałgany, $\mathrm{z}$ męczeńską cierpliwością czekali na odrobinę taniej żywności, wydawanej za kartkami.

Wiele tam ludzi padło $\mathrm{z}$ zimna i głodu, wielu śmiertelnie przemarzniętych wywieziono do szpitalów, to tylko Bogu jedynemu wiadomo.

I tak cierpieli prawie wszyscy po miastach - zarówno inteligent, jak i robotnik. Nędza jednako ogarniała wszystkich swoimi trupimi ramionami.

Kwarta - jednostka objętości: staropolska - 1,125 litra; angielska - 1,136 litra.

Pud - rosyjska jednostka wagowa liczaca 16,38 kg.

Inauguracyjne posiedzenie Tymczasowej Rady Stanu odbyło się 14 I 1917 na Zamku Królewskim w Warszawie. Zob. B. H u t t e n- C z a p s ki, Sześćdziesiąt lat życia towarzyskiego i politycznego. T. 2. Warszawa 1936, s. 325. 
A groza śmierci głodowej bratała.

Znam wiele rodzin inteligencji, które przejadłszy oszczędności, żyły potem powolną wyprzedażą mebli, pościeli, odzienia...

Znam takie rodziny, gdzie na ojca i dwóch synów pozostało jeno jedno palto. I znam takich, których wojna zastała w pięciu pokojach, ale po czterech latach gnieździli się już w suterenie i na cztery osoby posiadali dwa sienniki i jedną, literalnie jedną, kołdrę.

I to byli inżynierzy, adwokaci, artyści, handlowcy, technicy, literaci, nauczyciele - tysiące rodzin inteligenckich, których wojna pozostawiła bez środków.

Całe też tysiące rodzin żyło jeno kartoflaną zupa komitetową ${ }^{30}$ i strasznym chlebem kartkowym, palili w kominach raz na tydzień, a przez całe miesiące zimowe nie mieli światła w mieszkaniach.

Śmierć też kosiła ich niemiłosiernie.

Naturalnie w kraju wielkim jak Polska nie brakowało ludzi bogatych, zwłaszcza nie brakowało ludzi bogacących się na powszechnej nędzy, tzn. „paskarzy”, ludzi bez czci i sumienia, w ogromnej większości Żydów. Ale walka z lichwą wszelakiego rodzaju i „paskarzami” była niemożliwa. Opłacali się Niemcom i Niemcy się nimi serdecznie opiekowali. Bywały takie wypadki: sędzia Polak nakazał poaresztować największych spekulantów, lecz nim zdążył ich osądzić, Niemcy wypuścili ich na wolność, a sędziemu kazali podać się do dymisji.

A bywały i takie rzeczy: dwory i zamożniejsze wsie występowały z pomoca dla nędzy miejskiej, zbierały między sobą składki, ale głównie chciały pomagać żywnością, zbożem zwłaszcza i kartoflami. Niemcy pozwalali na takie braterskie pomoce, ale cóż kiedy ani jeden transport nie doszedł swego przeznaczenia. Ginął w niemieckich magazynach i kieszeniach.

Ale pomimo takiej ogólnej niedoli, nie było w narodzie rozpaczy; większość niezłomnie wierzyła w zwycięstwo koalicji i w zmartwychwstanie Polski.

Naród, mimo przeszkód straszliwych i mimo niemieckiej pięści wiszącej nad każda polska głową, prostował się coraz potężniej, patrzył ku dalekim jeszcze zorzom wolności, a zarazem brał się, jak mógł, do roboty. Dźwigał się, jak umiał, i budował, jak poradził. A wiedziony nieomylnym i świętym instynktem, zaczynał od szkoły.

Właśnie w czasie wojny, w najgorszych chwilach, często literalnie pod kulami, a zawsze wbrew Niemcom, otworzono tysiące szkół po wsiach i miasteczkach. Gdzie nie było odpowiednich budynków, tam uczono po chłopskich izbach, plebaniach albo i po stodołach. Tu i ówdzie same gminy uchwalały powszechne, obowiazkowe nauczanie i to swoim własnym kosztem. A gdzie Niemcy nie chcieli pozwolić na szkołe, tam nauczano tajnie, nocami. Bywały wsie, gdzie nauczyciel, aby nie wpaść w ręce niemieckich szpiclów, co noc sypiał w innej chałupie. Pęd do nauki wybuchał tak żywiołowy, że otwierano całe gimnazja, jak w Ojcowie pod Krakowem ${ }^{31}$, gdzie

30 Komitet Obywatelski organizował pomoc m.in. w postaci posiłków i odzieży. Zob. M. Pr z e n i o s ł o, Organizacje samopomocy społecznej $w$ Królestwie Polskim w latach I wojny światowej. „Niepodległość i Pamięć” 2011, nr 1.

31 Chodzi o Prywatne Gimnazjum Koedukacyjne w Ojcowie, które istniało w latach 1917-1922. 
chłopi z paru wsi złożyli czterdzieści tysięcy rubli na otwarcie tej szkoły, ale pod warunkiem, że ta szkoła ma być tylko dla Polaków.

Rzucono się do handlu. Utworzono bardzo wiele spółek i kooperatyw.

Broniono się wszelkimi sposobami przed nędzą, Żydem i Prusakiem.

A już chłopi w okolicach stratowanych przez wojnę dokonywali prawdziwych cudów pracy i wytrwałości.

Bywało często, że zaledwie skończyła się bitwa, zaledwie przetoczyły się dalej walczace ze sobą armie, a jeszcze dymiły popalone chaty, gdy chłop już powracał na rumowiska, w głowę się skrobał, medytował przez chwilę i splunąwszy w garście, zabierał się namiętnie do odbudowy spalonego gniazda.

Znane są też wypadki, że w okolicach tuż za bojowymi frontami chłopi, nie zważając na niebezpieczeństwa, orali i siali, absolutnie pod gradami kul.

Wielu z nich zapłaciło życiem lub ranami tę dziką żarliwość pracy.

W Lubelskiem, we wsi niedaleko Kraśnika, jeden $z$ tamtejszych gospodarzów wyszedł $\mathrm{z}$ pługiem $\mathrm{w}$ pole podczas srożącej się właśnie bitwy ${ }^{32}$.

Kule świszczały dokoła, szrapnele przelatywały mu nad głową i raz po raz wybuchały granaty, wyrywając straszliwe fontanny ziemi, a chłop jeno czapę nasadzał głębiej na uszy, niekiedy zezował na boki, czasem się żegnał, koniowi bata przykładał i nieulękle orał zagon za zagonem.

Zobaczył to jakiś moskiewski oficer, podjechał i woła zdumiony:

- Człowieku, bójże się Boga i uciekaj, bitwa przecież, mogą cię zabić.

Chłop spojrzał w stronę wołającego i tylko mruknął.

- Przecież to nie do mnie strzelają! Pola nikt za mnie nie zaorze!

I orał dalej.

Ten prosty chłop wyrzekł jedną z największych prawd:

„Pola nikt za mnie nie zaorze”.

Bowiem sami, własnymi rękami, w największym trudzie, w męce i wśród niebezpieczeństw i nieskończonych ofiar, musimy sobie odbudowywać ten wspaniały polski dom. Tylko tak budowany, będzie trwał wiecznie.

Już cały naród czuje tę prawdę, więc nic dziwnego, że ta ordynarna farsa, jaką Niemcy zagrali w listopadzie 1916 r., ogłaszając na Zamku Warszawskim niby to wolną i niezależną Polskę, nikogo nie oszukała.

Chyba jeno tych, którzy pragnęli być oszukanymi.

Niemcy zawiedli się srodze, przypuszczali bowiem, że po ogłoszeniu takiej Polski, naród oszaleje $\mathrm{z}$ radości, padnie im $\mathrm{w}$ ramiona, przysięgnie wierność i natychmiast utworzy wielką armię, która pójdzie wraz z nimi bić aliantów! $\mathrm{O}$ to im głównie chodziło! Tymczasem kiedy Beseler ${ }^{33}$, niemiecki generał-gubernator, powracał $\mathrm{z}$ tej hecy do Belwederu, na drugi koniec Warszawy przejeżdżał pustymi ulicami. I ani jeden głos nie podniósł się na jego przywitanie! Nie usłyszał ani jednego słowa wdzięczności. A zamiast entuzjastycznych okrzyków - spluwano pogardliwie.

33 Hans Hartwig von Be seler (1850-1921) - niemiecki generał, który od 1915 roku pełnił funkcję gubernatora Warszawy. 
Gorzko się później uskarżał na polską niewdzięczność.

Tymczasem po skonaniu suchotniczej „Rady Tymczasowej” stworzono Regencję i Gabinet Ministrów ${ }^{34}$. Myśleli z tępym, pruskim uporem, że może nareszcie Polska da się wziąc chociaż na ten pseudorząd i w końcu im uwierzy.

A kraj się śmiał z tego niby polskiego rządu, stworzonego w Berlinie i Wiedniu, ku wygodzie zaborców i otumanieniu całego świata.

Bowiem Polska miała wtedy swój własny, cichy i tylko moralny rząd, którego stworzyła i którego wskazań słuchała. Było to „Koło Międzypartyjne” 35 złożone z przedstawicieli stronnictw stojących na gruncie narodowym i pod hasłem: „Wolna. Cała i Niepodległa”. Koło obejmowało wszystkie trzy zabory i prowadziło prawdziwie polską politykę w porozumieniu z naszymi organizacjami za granica, w Szwajcarii, Londynie, Paryżu, a potem i w Ameryce.

A niesłychanie trudno było się wówczas porozumiewać ze światem. Żyliśmy przecież w więzieniu pilnowanym przez okopy i miliony bagnetów. I niemiecka sroga cenzura czuwała nad nami. I tajna pruska policja wciąż deptała nam po piętach. Prasa nasza była zakneblowana! Musieliśmy stworzyć tajną prasę, żeby ostrzegać szeroki ogół przed niemieckimi machinacjami, i informować o tym, co się naprawdę dzieje na świecie.

Naturalnie, ci, którzy wyznawali proniemiecką orientację, mogli swobodnie komunikować się ze światem, mogli wyjeżdżać za granicę, mogli agitować po Kraju, mogli zwoływać wiece i wymyślać w swoich gazetach na aliantów i na nas, co im się tylko podobało.

Niezależnie od tych moralnych kajdan, jakimi Niemcy skuwali nas codziennie i coraz silniej, nędza w kraju rosła $z$ godziny na godzinę. I gdyby nie braterska pomoc Poznańskiego, które przysyłało nam miliony marek, i gdyby nie Sienkiewiczowski Komitet w Vevey ${ }^{36}$, w Szwajcarii, otrzymujący wielkie zasiłki od was z Ameryki, to pół ludności naszych miast i miasteczek musiałoby wymrzeć z zimna i głodu. Zwłaszcza że trzeba było pomagać i Galicji.

W historii tej wojny na ziemiach naszych Galicja musi zająć jedną z najtragiczniejszych kart. Będzie to prawdziwa martyrologia tej nieszczęsnej prowincji. Rząd austriacki ograbił ja zaraz na poczatku, a potem straszne fale najazdów niszczyły raz po raz. I jakby nie dość tych klęsk straszliwych, rząd austriacki wybrawszy wszystkich mężczyzn do wojska i wypędziwszy do obozów koncentracyjnych dziesiątki tysięcy, gdzie masowo wymierali, oddał kraj na pastwę węgiersko-żydowskich zbójów. Hulali też sobie po Galicji gorzej niźli kiedyś Tatarzy! Nie ma takiej zbrodni ni nikczemności, ni złodziejstwa, którego by ta zbójecka banda nie popełniła! Odznaczył się szczególnie arcyksiążę habsburski Józef ${ }^{37}$, przezwany „wieszatelem” ${ }^{38}$, gdyż miał specjalne upodobania, przyglądając się wieszaniom ludzi. A powieszono

Zob. Z. J. W in n i c ki, Rada Regencyjna Królestwa Polskiego i jej organy (1917-1918). Wrocław 2017.

Międzypartyjne Koło Polityczne - organizacja polityczna działająca w latach 1915-1918.

W styczniu 1915 z inicjatywy H. Sienkiewicza, I. Paderewskiego i A. Osuchowskiego powołano do życia Komitet Generalny Pomocy Ofiarom Wojny w Polsce. Był on zaangażowany w zbiórki pieniędzy, żywności oraz przekazywanie ich do ojczyzny.

Chodzi o arcyksięcia Józefa Augusta Habsburga-Lotharingiena (1872-1962).

„Wieszatiel” (ros.) - kat, wieszak. 
w czasie wojny w Galicji przeszło trzydzieści tysięcy Polaków! Wieszał arcyksiążę i wieszali jego podkomendni. Starczyło podejrzenie o zdradę Austrii, a wnet nieszczęsny już wisiał. Znaleźli bieliznę na płocie, jaką kobieta suszyła: daje sygnały Moskalom: powiesić! Chłop powiedział nazwę wsi, o jaka pytał jakiś oficer węgierski, wymówił tę nazwę po swojemu. Wprowadza w błąd armię, winien zdrady stanu: powiesić! Znaleźli w chałupie worek mąki kupionej od Moskali! Szpieg moskiewski: powiesić! Znaleźli ruble, które chłopina składał za różne sprzedane przedmioty: powiesić! W jakimś kościele zadzwoniono na intencję zmarłego właśnie chłopa. Dają sygnały moskalom: powiesić księdza! W jakiejś wsi Węgier, oficer, nie mógł się rozmówić, bo nikt tam po węgiersku nie rozumiał! - powiesić co dziesiątego! Najbłahsza, nigdy nie sprawdzana denuncjacja byle Żyda wystarczała i człowiek wisiał! Nawet za to, że ktoś powiedział o Franciszku Józefie, iż zgłupiał ze starości. Powieszono nieszczęsnego żartownisia. Wieszano po drzewach przydrożnych, po lasach, wieszano nawet na ramionach krzyżów. Niepodobna mi tego opowiadać dalej, krew ścina się ze zgrozy.

I tak się nasze życie ciągnęło do 1917 r., ciężkie, okropne i beznadziejnie długie. Pierwszy głos prezydenta Wilsona o Polsce ${ }^{39}$, przemycony jakimś cudem do kraju, wstrząsnął Polską niby potężny orzeźwiajacy prąd elektryczny. Zaśpiewały w duszach nadzieje. Setki tysięcy dziękczynnych adresów złożono w konsulacie amerykańskim. Odbywały się wielkie i serdeczne manifestacje na cześć Ameryki, zresztą rozpędzane bagnetami niemieckich pachołków.

Zasię później nieco, kiedy już Ameryka wypowiedziała wojnę i cały świat podniósł się zbrojnie przeciwko Prusakom, odetchnęliśmy z radosną ulgą. A w marcu tegoż roku, kiedy carat rosyjski rozsypał się w gruzy i ludowe przedstawicielstwo Rosyjskiej Republiki ogłosiło uznanie praw Polski, wiedzieliśmy wtedy to jedno, że nam trzeba tylko wytrzymać i przetrzymać!

Do tego przetrzymania pomogliście nam niesłychanie, rodacy.

Pewnego bowiem dnia na wiosnę 1917 rozeszły się po kraju dziwne wieści o was i o Paderewskim ${ }^{40}$ ! Słuchaliśmy z zapartym tchem, ze łzami, w gorączce, a wieści przylatywały coraz piękniejsze i większe, dzwoniły nam niby pieśni skowronkowe na wiosnę - że tworzycie polską armię i miliony dajecie na Polskę. Serca nam wzbierały dumą i radosną wdzięcznością. Modlono się za was po kościołach i msze odprawiano na waszą intencję.

$Z$ waszego patriotyzmu i ofiarności czerpaliśmy siły.

$\mathrm{Z}$ uniesieniem czytaliśmy o gigantycznych wysiłkach Ameryki.

8 I 1918 Th. Woodrow Wilson wygłosił orędzie do Kongresu USA. W 13 punkcie orędzia postulował: „Należy stworzyć niezawisłe państwo polskie, które powinno obejmować terytoria zamieszkane przez ludność bezsprzecznie polską, któremu należy zapewnić swobodny i bezpieczny dostęp do morza i którego niezawisłość polityczną i gospodarczą oraz integralność terytorialną należy zagwarantować paktem międzynarodowym” (cyt. za: L. G e r berg, Prawo międzynarodowe $i$ historia dyplomatyczna. Wybór dokumentów. T. 2. Warszawa 1958).

40 Prawdopodobnie chodzi o tzw. Memoriał Paderewskiego, który został ogłoszony 11 I 1917 i zawierał koncepcję Stanów Zjednoczonych Polski. Nowa państwowość miała być zbudowania z: Królestwa Polski, Królestwa Litwy, Królestwa Polesia, Królestwa Galicji-Podola, Królestwa Wołynia. Memoriał 19 kart maszynopisu z odręcznymi poprawkami - przechowywany jest w Archiwum Akt Nowych w Warszawie. 
Cudowna bajką wydawało się to transportowanie przez ocean setek tysięcy żołnierzy w przeciagu miesiąca.

I całym żarem serc błogosławiliśmy rycerzom Ameryki, walczącym bohatersko przy boku Francji, Anglii i Włoch ze wspólnym naszym wrogiem.

Ale godzina ostatecznego zwycięstwa była jeszcze daleka.

Niemcy bowiem jeszcze wcią̇ zwyciężali!

Jeszcze przyszedł atak straszliwy na Verdun ${ }^{41}$ ! Na drugi czy trzeci dzień, po zdobyciu pierwszych fortów, Niemcy urządzili po ulicach Warszawy tryumfalna paradę! Przy dźwiękach fanfar, przy zwycięskich śpiewach olbrzymi pochód z pochodniami krążył po mieście całymi godzinami. Zwycięska radość, upojenie i pycha biły z każdej niemieckiej twarzy! Dzikie tryumfalne śpiewy rozlegały się przez cała noc! Po wszystkich koszarach, klubach i urzędach bankietowano i pito na cześć zdobycia Verdun. Nadzwyczajne dodatki niemieckich gazet przysięgały, iż zdobycie tej fortecy to kwestia jeszcze paru godzin. A myśmy musieli na to wszystko patrzeć, musieliśmy słuchać i musieliśmy zacinać wargi, a zaciśnięte pięście schować w kieszenie.

Na szczęście Verdunu nie zdobyli, a niemieckie sny o potędze prysnęły. Jeszcze wielu w Polsce zginęło $z$ nędzy, wielu padło na polach bitew, wiele łez się polało i wiele cierpień musiał kraj przenieść.

Jeszcze przyszło bolszewickie panowanie w Rosji, i straszne rzezie Polaków na obszarach rozpadnię[te]go imperium. Nikczemne, wołające o pomstę do nieba wyniszczanie polskiego żywiołu na Litwie, Białej Rusi i Ukrainie, zainicjowane przez Niemców i Żydów, a wykonane rękami bolszewickich obłąkańców. Jeszcze spadł na nas traktat zawarty w Brześciu Litewskim ${ }^{42}$.

I ostatnia wielkanocna ofensywa niemiecka na wiosnę 1918 r. ${ }^{43}$, tak groźna z początku, tak zwycięska i zdawało się niepowstrzymana, że wielu ludzi, czytając niemieckie biuletyny, nie mogło się powstrzymać od serdecznego płaczu.

Aż nareszcie doczekaliśmy się dni tryumfów.

Szala zwycięstwa przeważyła się stanowczo na stronę aliantów.

I Polska wtedy targnęła się; naród począł się prostować i w sobie skupiać, nabierać tchu i gotować do walki.

Na czele kraju po niedołężnej regencji stanął Polak niezłomny, bożyszcze młodzieży, twórca legionów, żołnierz, wódz i organizator. J. Piłsudski.

A zwycięstwa aliantów już szły za zwycięstwami.

I kiedy nadszedł 11 listopad ${ }^{44}$, dzień w którym Niemcy podpisali zawieszenie broni, stał się cud nieoczekiwany nawet w marzeniu.

Powstała Warszawa, za nią cały kraj, i w trzech dniach wypędzono Niemców i Austriaków. Sama Warszawa miała przeszło 20 tysięcy niemieckich żołnierzy i urzędników. Ośmiuset zaledwie legionistów, chłopców z Polskiej Organizacji Wojskowej i Skautów rzuciło się niby stado lwów na te niemieckie hordy. Uderzyli,

41 Najbardziej intensywne walki toczyły się pod Verdun na przełomie lutego i marca 1916. Mający duże znaczenie strategiczne Fort de Vaux został zdobyty przez Niemców 7 VI 1916.

42 Traktat pokojowy zawarty 3 III 1918.

43 Ofensywa rozpoczęła się 21 III 1918.

44 Tego dnia podpisano rozejm w Compiègne. 
a zwycięstwo poszło ich śladami. Garść bohaterów przemogła groźne tysiące. Niemców ogarnął paniczny strach i widząc niechybną śmierć, oddawali się na łaskę i niełaskę, na kolanach żebrząc o zmiłowanie.

Łowiono ich po ulicach, wyciagano $\mathrm{z}$ biur i koszar, wleczono $\mathrm{z}$ piwnic, gdzie się tchórzliwie poukrywali. Widziano wtedy, jak dziewczęta rozbrajały generałów, jak dwunastoletnie chłopaki rzucały się na całe uzbrojone kompanie, jak jeden zbrojny legionista pędził przed sobą uciekające w panice bataliony, jak garść robotników $\mathrm{z}$ gołymi rękami brała w niewolę baterię artylerii i ogromne wojskowe magazyny.

I tak samo działo się po wsiach, miasteczkach i miastach, gdyż skoro jeno rozległ się potężny głos z Warszawy: na Niemca! Co jeno żyło, co jeno mogło utrzymać w garści drag, widły czy strzelbę, jednako chłopi, panowie i robotnicy, wszystko rzuciło się na wroga. Powiał huragan, zawrzała krew, zacisnęły się pięście, zwarły się dusze i runęli na wrogów nieprzełamaną ławą, przemogli, zbili, rozbroili i wypędzili z kraju niby wściekłych psów.

A niewielu Niemców zginęło w tych walkach, bo na kolanach skamłali o miłosierdzie, więc jeno ten i ów dostał kijem przez łeb i nogą na drogę...

Widziałem na szosie kaliskiej, prowadzącej do Berlina, tysiące rozbrojonych Niemców: maszerowali, podpierając się kijami; szli skromni, potulni, cisi, a pokornie się kłaniający każdemu spotkanemu chłopu - wracali do Vaterlandu. A po wsiach, przez które przechodzili, po wsiach ograbianych przez nich i łupionych bez miłosierdzia, przyglądał się im lud surowo, ale nie brał pomsty za ich poprzednie zbrodnie i gwałty, tyle jeno, że tam któryś z nich podkpiwał:

- Te, faja, nie uciekaj tak prędko, bo zgubisz pludry ${ }^{45}$ !

- A czemu to nie uciekacie na koniach, któreście nam pokradli?

Przerwał te żarty jakiś stary gospodarz i rzucił z powagą.

- Dajcie im spokój, dosyć spokornieli, a bieda nauczy ich jeszcze rozumu.

I tylko w taki sposób mścił się polski lud za swoje krzywdy.

I na tym powinienem już skończyć te pobieżne wspomnienia.

Ale na zakończenie jeszcze parę słów.

Oto przynoszę wam z Polski najgłębsze podziękowania za waszych synów lejących ofiarną krew za ojczyznę, za wasz szczodry grosz na świętą sprawę dawany, i za wasze wierne, szlachetne serca.

Niepodobna mi w słowach wyrazić wszystkiej braterskiej wdzięczności, jaka czuje dla was każda polska dusza tam, w starym kraju.

Spełniliście swój obowiązek i za to wam cześć!

I jeszcze jedno.

Polska wstaje $\mathrm{z}$ grobu niby Łazarz; wstaje naga, w ranach, w kurzawie krwi, w ciężkich bojach, jakie musi toczyć na wszystkich swoich granicach; wstaje potężna, lecz jeszcze osłabiona przebytymi cierpieniami, więc wyciaga ramiona do wszystkich swoich dzieci rozproszonych po całym świecie i woła: pomóżcie okryć 
moją nagość, zaleczcie moje rany, wesprzyjcie moje siły, nakarmcie moich głodnych - pomóżcie...

Kto Polsce pomaga - sobie pomaga i własną wolność i szczęście buduje.

Rodacy!

Podnieście dumnie głowy, wyprostujcie przygięte grzbiety, bo oto imieniem wolnej Polski was witam i mówię: opadły już wasze kajdany, nie jesteście już niewolnikami, nie jesteście już bezdomnymi sierotami, które każdy mógł poniewierać bezkarnie - jesteście równi wszystkim na świecie, jesteście wolnymi obywatelami Najjaśniejszej Rzeczpospolitej Polskiej!

Chicago, czerwiec 1919 r. Wł. St. R.

\section{Abstract \\ WŁADYSŁAW REYMONT'S WAR MEMORIES AN UNKNOWN MANUSCRIPT}

Edited by

DARIUSZ PACHOCKI John Paul II Catholic University, Lublin

The Kosciuszko Foundation Archive treasures a manuscript by Władysław Reymont. Its origin is chiefly connected with the writer's diplomatic mission in the USA where he was sent by the then Ministry of International Affairs. His main duties of the future Noble Prize winner were promoting the idea of reborn Poland among the Polish émigrés, striving to find funds to rebuild it and inducing the émigrés to repatriation. Touring the American cities, Reymont delivered over 30 speeches, which was great effort to him not only due to organisation but also as far as his health condition are concerned, all of which is well documented in his letters to family and friends (placed in commentaries to the text). The memories, apart from a description of occupation reality, contain an unusually vivid and touching account of the first days after regaining independence. 